\title{
Johanna Domokos: Endangered Literature. Essays on Translingualism, Interculturality, and Vulnerability.
}

Budapest: Károli Gáspár University of the Reformed Church in Hungary

\& L'Harmattan Publishing, 2018, 196 pages.

21st century literature presents a rather ambivalent situation: authors are either making a shift from their minoritarian language to that of the majority or are writing in more than one language. At the same time, there is a general consensus that the past several decades of contemporary literature have seen an unparalleled rise in migrant writers who find themselves confronted with new challenges. A statistical comparison from a longer, diachronic perspective would perhaps debunk this statement. Nevertheless, it indicates a paradigmatic shift away from the "monolithic" and exclusive understanding of a nation's literature and history. In the same vein, national literary fields have gradually been reinventing themselves as being conscious and supportive of literary diversity.

Johanna Domokos is a Hungarian scholar from the Transylvania region of Romania. Her multilingual and multicultural background has been bolstered through her studies in Cluj/Kolozsvár, Budapest and Berlin, together with her teaching experience in California (USA) and Germany. She currently serves as a professor at the University of Bielefeld and the Károli Gáspár Calvinist University in Budapest. Her focus on minority and translingual issues, mainly of the Uralic peoples, is not limited to her vast expertise as a scholar, editor, and teacher, but also includes translation work (translating from Sámi and Finnish, among other languages) and original contributions in the field of contemporary multilingual poetry with her own poems (e.g. Exile, Elixier. Poems, versek, Gedichte. 2012; Revolver. 2018).

In her book, Domokos addresses two phenomena or phenomenal aspects of literary diversity. On the one hand, she examines the literature of endangered languages and elaborates a paradigm of endangerment both from a linguistic as well as literary point of view. On the other hand, her work focuses on the thematic, formal and stylistic aspects of multilingual and translingual literary texts. The book consists of thirteen original studies; those which had already been published (approximately half) have been revised and re-edited. The book is divided into four parts; though each of the studies takes on a clear, thematic direction, the three major focal points of the book (namely endangerment, interculturality and translingualism) pave the way for an analysis of several related literary phenomena, such as literary ecology, écriture multiculturelle, code-switching and intercultural dialogism.

The first part, "On Vulnerability of Literature", starts with a study inquiring into what is to be considered endangered; it uses various categorizations and takes into account both the literary and linguistic aspects. The Uralic languages are used as an example here. The classification of the (Uralic) languages as vulnerable and endangered is not up for debate in this case. However, a few surprising points are made in Domokos's catalogue of languages. How can Akkala Sámi be classified as a critically endangered language if its last remaining native speaker was murdered by a Russian robber on 29 December 2003? It is worth noting that this case is notorious among Uralists and the Uralic peoples for symbolizing the destiny of minorities under Russian rule. Another questionable point that is raised relates to the mention of "Kainu Sámi", allegedly thought to be a Sámi language 
spoken in the Finnish region of Kainuu. Unlike other extinct Uralic languages - whether less documented (Kamassian, Mator etc.) or completely, except for their preserved place names, undocumented (Meshchera, Muroma, Merya) -, whose ethnonyms or glottonyms have nevertheless survived, the newly invented term Kainu Sámi, referring to a distinct language and to a taxon of language classification, should be used with caution. Along the same vein, one should then also speak of Pomorian or White Sea Sámi, North Karelian Sámi etc., i.e., the hypothetical Sámi languages spoken in the historical Sámi areas. It is possible that in the list of extinct Uralic languages, Kainu Sámi was mistaken for Kemi Sámi, an extinct, but comparatively well-documented language. The second study in this part of the text contemplates the relationship of the term endangered literature to digital humanities, literary scholarship, computational linguistics as well as documentary linguistics and citizen science; it explores the shift from print to the digital documentation of literature, as well as the consequences of this transition in the literary field of endangered languages. The third study describes the factors which influence the vulnerability of the Sámi literary field. It is grounded in a broad empirical survey carried out by Domokos and her fellow Sámi scholars in Finland, Sweden, Norway and Russia during the years 2017-2018, and is supplemented with specific suggestions for improving the weaker aspects of the literary field.

The second part, "Literary Ecology and Endangerment", begins with the chapter "On the ecology of cultural interference". Domokos introduces four modalities of cultural interference, classified according to their symmetric or asymmetric (hierarchical) relations and the changes spurred by these relations, described as four types of "dynamism". Interferences between immigrant Baltic, indigenous Sámi and the domestic Nordic literary fields serve as examples of such an interferential typology. The second chapter, which focuses on écriture multiculturelle, takes a heuristic look at multiculturality in Finnish literature at the levels of context, intertext, and text. It applies a multicultural perspective to the Finnish literary field and general social processes as shaped by the rapid growth of ethnic diversity heralded by the arrival of the 21st century; an increasing number of Finnish authors now identify with multiple cultural spheres. This chapter reflects on the configuration of individual actors in this literary field along with the narrative and linguistic structure of multicultural textual worlds; it examines the role and function of cultural interference and its prescribed value throughout Finnish literary history: the literary field of Finland's literature (literature written in Finland in any language, Suomen kirjallisuus in Finnish) has always been multicultural in its essence. What could have been specified more closely is which multicultural efforts of the dagdrivare movement are being referred to here (p. 67); the movement as such can also be interpreted as very Finland Swedish in nature, rather than truly multicultural. The last chapter in this section focuses on the phenomenon of writers with multilingual backgrounds living in Finland who choose to mix two or more languages in their literary works; the most suitable term here proves to be code-switching. The multilingual landscape in Finnish literature can be mapped out in terms of six major groups: 1) Finnish and Finland-Swedish authors engaging with cultural encounters; 2) indigenous Sámi authors; 3 ) historical minorities (Roma, Jewish, Mishar Tatar and Russian authors); 4) authors who migrated outside of Finland (Sweden) or who are representatives of Finnish minorities (Meänkieli in Sweden or Kven in Norway), and repatriated Finnic (i.e., not only Finnish, but also, e.g., Karelian) authors; 
5) writers from diverse cultural backgrounds (Finnish-Estonian, Arabic-Finnish etc.); 6) "transient" writers who live in the country only briefly but who contribute to the multiculturalization of the literary landscape. The article reflects on literary code-switching in a selection of works by these authors with respect to grammatical structure, aesthetic production, and socio-cultural significance.

The entire third part, "Sámi Literature in the Age of Language Endangerment", is devoted to Nils-Aslak Valkeapää (1943-2001), an author, musician, visual artist, activist, politician and spokesman for the Sámi, the indigenous Northern European people. Valkeapää became the leading poet of the Sámi literary renaissance of the 20th century. Following his literary début in 1971, he published nine volumes of poetry in the North Sámi language. In addition to literature, his books contain paintings, graphics, musical notation, and photos; Valkeapää sang and composed numerous yoiks. The first study in this part of the text is devoted to his fifth book, the Nordic Literary Prize-winning work Beaivi, Áhčážan (1988; in English The Sun, My Father, 1997) and the central aspects of his book: process- and agent-driven untranslatability and how it relates to literary diversity, e.g., in addition to approximately fifty reindeer names, Valkeapää also includes nearly a hundred words referring to other aspects of reindeer herding, thereby offering a glimpse into North Sámi reindeer-herding terminology. The second chapter explores the narrative strategies of Valkeapää's first work Terveisiä Lapista (1971; Eng. Greetings from Lapland) and the book's edited and translated Norwegian (1979), English (1983), and German (2014) versions. Special attention is paid to how intercultural dialogism manifests both in the original work and in the translated adaptations. In the third study, following a brief reflection on the two major approaches to how liminality operates in the works of Valkeapää, Domokos focuses on liminal patterns in the author's texts (termed "scripted liminality") and performances (termed "embodied liminality"), illustrated using his only drama Ridn'oaivi ja nieguid oaidni (Eng. The Frost-Haired One and the Dream-Seer).

The first chapter in the fourth part of the text, "Thematic, Formal and Stylistic Aspects of Literary Translingualism", is theoretical and deals with the question of intralingual, interlingual and intersemiotic literary translingualism. The second study concerns Cia Rinne's two books of conceptual poetry $(2001,2009)$; Rinne was inspired by the multilingual neighbourhood where she grew up (she was born to Finland-Swedish and Finnish parents in Sweden, who moved to Germany shortly after her birth). Her works contain typewritten, multilingual texts shaped into poetic forms; verbal idioms, clichés and philosophical reflections are structured along patterns of wordplay. Linguistic elements are accompanied with diagrams and with references to transcultural movements and philosophers of language. The main focus of Domokos's analysis is translanguaging: how it is thematically formulated and how it is formally and stylistically modelled in texts. The different techniques employed throughout this process are shown to make the reader conscious of how signs acquire the power of the symbolic and how they shape languages. The third study in the final part traces the influence of the Hungarian prose tradition on the writing style of the Hungarian-born German writer Terézia Mora, who moved to Germany at the age of 19, and also explores how Hungarian existential poetry is manifested in the imagery of her 2013 novel, Das Ungeheuer (The Monster). By focusing on instances of literary translingualism, Mora's prose is contextualized within the 
double framework of Hungarian as "source literature" and German as "target literature", as it offers a combination of two different narrative trajectories in a unique narrative tone. Literary translingualism is thus considered a dynamic process whereby authors like Mora navigate between literary worlds through the strategic employment of diverse poetic and aesthetic resources. The last study briefly mentions the innovative techniques of Finnish-Hungarian artist Sándor Vály in his German-language musical performance Toteninsel (The Isle of the Dead). Toteninsel is originally a painting by Swiss symbolist artist Arnold Böcklin (1880-1886). In 1919, Karl Georg Zwerenz wrote a libretto titled Die Insel der Toten, which Vály discovered nine decades later and decided to reimagine with an accompanying musical composition. His performance lends itself to different cross-cultural interpretations; the piece is based on the interplay of acoustic and linguistic elements, which work together to reveal an instance of intermedial translanguaging.

Domokos's monograph serves as a successful attempt at combining linguistic and literary studies. Its structure is deductive: it begins by making broader, general statements and grows more specific in nature towards the end. Nevertheless, the purpose of the deductive approach is to demonstrate the applicability of the general considerations towards illustrative examples from selected texts. ${ }^{1}$

Jan Dlask, Michal Kovár

https://doi.org/10.14712/24646830.2021.17

1 This work was supported by the European Regional Development Fund project "Creativity and Adaptability as Conditions of the Success of Europe in an Interrelated World" (reg. no.: CZ.02.1.01/0.0/0.0/ 16_019/0000734). 